\title{
Physico-Chemical and Biological Characteristics of the Nklobisson Artificial Lake in Yaounde, Cameroon
}

\author{
Josephine Ndjama1, Gideon Aghaindum Ajeagah², Ndondo Gustave Raoul Nkoue ${ }^{3}$, \\ Wirmvem Mengnjo Jude', Ngon Eric Belmond Birama ${ }^{1,2}$, Gloria Eneke Takem Eyong1, \\ Andrew Ako Ako', Mohamadou Bello ${ }^{1}$, Tchouya Romaric Victorien Ntchantcho', \\ Joseph Victor Hell1
}

${ }^{1}$ Institute de Recherche Geo-miniere du Cameroun, Yaounde, Cameroun

${ }^{2}$ Laboratory of Hydrobiology and Environment, Université de Yaoundé 1, Yaoundé 1, Cameroun

${ }^{3}$ Deparetement des Sciences de la terre, Université de Douala, Douala, Cameroun

Email:ndjama72@yahoo.fr, ajeagahg@yahoo.com,raoulnkoue@yahoo.fr

How to cite this paper: Ndjama, J., Ajeagah, G.A., Nkoue, N.G.R., Jude, W.M., Birama, N.E.B., Eyong, G.E.T., Ako, A.A., Bello, M., Ntchantcho, T.R.V. and Hell, J.V. (2017) Physico-Chemical and Biological Characteristics of the Nklobisson Artificial Lake in Yaounde, Cameroon. Journal of Water Resource and Protection, 9, 15471563.

https://doi.org/10.4236/jwarp.2017.912098

Received: October 5, 2017

Accepted: November 27, 2017

Published: November 30, 2017

Copyright $\odot 2017$ by authors and Scientific Research Publishing Inc. This work is licensed under the Creative Commons Attribution International License (CC BY 4.0).

http://creativecommons.org/licenses/by/4.0/ (c) (i) Open Access

\begin{abstract}
The deterioration of water quality in lakes constitutes an environmental problem faced by humanity. The Nkolbisson artificial lake which is located downstream of the Abiergue and Mintotomo streams in Yaounde is under the influence of various forms of pollution, mostly resulting from human activities. There is proliferation of algae on the lake surface that consumes the available oxygen in the lake. The main objective of the current study is to evaluate the different forms of pollutants in the lake, in order to propose efficient solutions for a suitable management strategy, basing on the physico-chemical and biological analysis. The lake retains an average of 2535.49 tons/year of suspended solids in the rainy season and 1438.05 tons/year in the dry season. The range of dissolved oxygen $(5.2-3.8 \mathrm{mg} / \mathrm{l}) ; \mathrm{pH}(7.8-6.8)$; temperature $\left(23.9^{\circ} \mathrm{C}-23.1^{\circ} \mathrm{C}\right)$; electrical conductivity $(266.1-87.3 \mu \mathrm{S} / \mathrm{cm})$; turbidity $(22.3$ $10 \mathrm{UNT}$ ); suspended solid (240 - $40 \mathrm{mg} / \mathrm{l})$; BOD (55 - $8 \mathrm{mg} / \mathrm{l})$; COD (76 - 87.3 $\mathrm{mg} / \mathrm{l})$. Biologically, faecal coliforms fluctuates between $\left(42 \times 10^{2}-425 \times 10^{3}\right.$ FCU/100 ml), faecal streptococci $\left(8 \times 10^{3}-158 \times 10^{3} \mathrm{FCU} / 100 \mathrm{ml}\right)$ and total Coliform $\left(15 \times 10^{3}-78 \times 10^{6} \mathrm{FCU} / 100 \mathrm{ml}\right)$ evidence that, the studied lake is highly polluted. Consequently the lake retains an average of 2888.7 tons/year of suspended matter.
\end{abstract}

\section{Keywords}

Biological, Physico-Chemical, Pollution, Artificial Lake, Cameroon 


\section{Introduction}

Urbanization and increasing industrialization of cities result in an increase in the load of wastewater that is enriched in organic matter and dissolved substances. The outcome is a deterioration of water quality, reduction of diversity, and on a long-term, the disappearance of water bodies [1]. Artificial lakes in Cameroon are increasingly faced with sedimentation problems. While many studies have been carried out on the filling of lakes in Europe and America in general, little is known in Africa [2]. In Cameroon, some works done by Zébazé Togouet et al. [3], Foto Menbohan et Njine [4] show respectively that, the Yaoundé municipal and the Effoulan lakes represent major assets to support the country's development but they are threatened by hydrological changes, pollution and siltation problems.

Siltation and eutrophication of lakes cause flooding, significant changes in the physicochemical and biological parameters and consequently rapid growth of aquatic plants [5]. The Nkolbisson artificial lake was created in the 1970s by the Higher National School of Agriculture in order to facilitate the training of engineering students in various disciplines (viticulture, irrigation experimental fields, fishing competitions and water skiing). After the closure of the school, all activities were definitely stopped in 1980 . The continuous drainage into the lake of untreated wastewater from the Abiergue and Mintotomo streams of the Mefou watershed flowing across Cité Verte from the rivers of the Mefou watershed and the Abiergue, Mintotomo, Cité verte located upstream, as well as the wastewater treatment plant of Camps Sic Cité verte, has gradually degraded its quality and environment [6]. Despite the dangers inherent in the filling of lakes over time, no study has yet been undertaken on the Nkolbisson artificial lake; one of the oldest artificial lakes in Yaoundé Bessenassé [7]. Okasha et al. [8] indicate that siltation of lakes results in the reduction of their lifespan, one of the most harmful effects of water erosion. The management of lake ecosystems, therefore, requires a thorough knowledge of the hydrodynamical and sedimentary operation to propose scenarios of changes that are adapted to different environmental constraints. These include maintenance of water quality, improvement of fish habitat and aquatic organisms habitat, protection of structures, development of recreational and ecotourism activities [9] [10]. This study is one of the first studies that focus on the filling of the Nkolbisson artificial lake. This work aims at diagnosing the parameters that contribute to the degradation and filling rate of the Nkolbisson artificial lake and to propose approaches to ensure its restoration and sustainable management. Therefore, it is necessary to avoid refilling the lake that disequilibrates the Nkolbisson artificial lake which represents a touristic site to the urban community.

\section{Geological Setting}

The studied lake $\left(3^{\circ} 87^{\prime} \mathrm{N}\right.$ and $\left.11^{\circ} 52^{\prime} \mathrm{E}\right)$, is located at Nkolbisson within the Yaoundé VII Sub-Division (Figure 1). The vegetation is made up of forest, Sterculiaceae and Ulmaceae which is highly degraded by urbanization [11]. The 


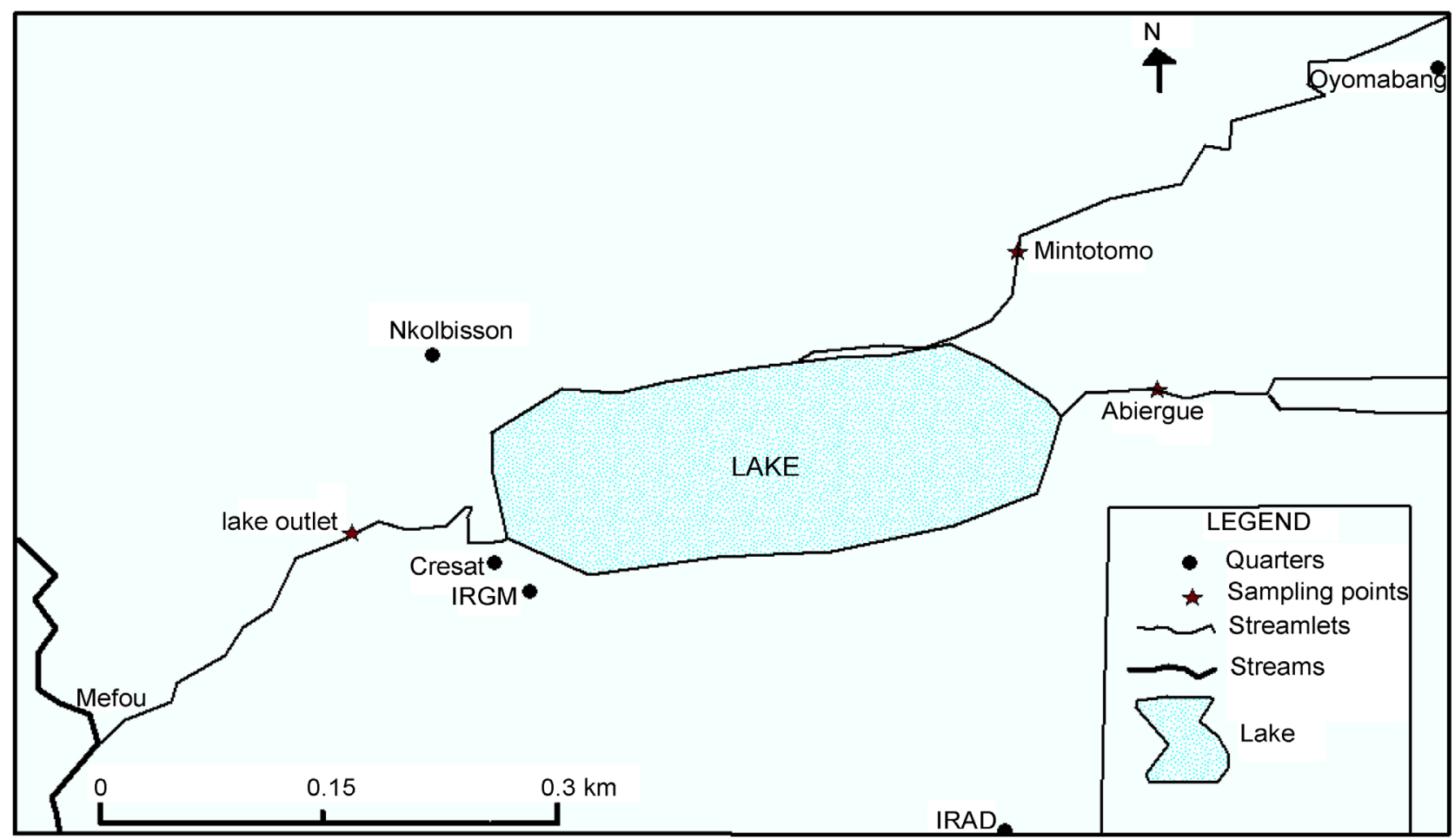

Figure 1. Map of the Nkolbisson artificial lake indicating the different tributaries.

area is dominated by lateritic soils with minor hydromorphic subsoils [12]. The hydrographic network is dense, made up of many low and marshy funds including the Mefou River which is flowing through the southern part of the Nkolbisson neighborhood. The climate is characterized by two rainy seasons (September to mid-November and mid-March to June) with an annual average temperature of $23.5^{\circ} \mathrm{C}$.

\section{Analytical Methods}

The choice of the sampling points was not easy due to many factors including the rough morphology of the studied area, the multiplicity and the diversity of wastes. However, basing on the source of materials flowing into the lake, three water sampling points representing the streams feeding the studied lake were chosen: 1/Abiergue which is, situated upstream of the Lake, 2/Mintotomo, main tributary of Abiergue which crosses the undeveloped rural area and 3/the outlet of the studied lake (Figure 1). Samples were collected both during raining season (two sets of sampling) dry season (two sets) within the period 2013 to 2014 . Given that the biodegradation of suspended matters in waste water takes place at a very fast rate, physicochemical parameters including temperature settings $(\mathrm{T})$, $\mathrm{pH}$, dissolved oxygen (DO) and electrical conductivity (EC) were measured using a mercury thermometer, $\mathrm{pH}$ meter (Schott CG 818 Geräte $\mathrm{GmbH}$ ), an Oximeter (OXI model 315i WTW) and conductivity meter mark $\mathrm{HACH}$, respectively. Turbidity was measured using turbidity meter (HANNA instrument model LP 2000) at LAGE Laboratory, Yaoundé. Suspended solids (SS) were 
measured using a brand of Millipore filtration ramp WHATMAN GF/F $47 \mathrm{~mm}$ circular diameter with porosity $0.45 \mu \mathrm{m}$. The liquid debit was estimated by the volumetric method and the solid debit was calculated from the average concentration of suspended solid (SS) using the equation.

$$
Q_{s s}=Q_{L} \times C
$$

where $Q_{s s}$ represents the debit of suspended solid $\left(\mathrm{kg} \cdot \mathrm{s}^{-1}\right) ; Q_{L}$, the debit of liquid $\left(\mathrm{m}^{3} \cdot \mathrm{s}^{-1}\right)$ and average of concentration of suspended solids $\left(\mathrm{g} \cdot \mathrm{L}^{-1}\right)$.

The annual flux of suspended solids transported by the Abiergue and Mintotomo was finally obtained by summing up the solid input of the stations which supply the lake.

The liquid flow rate was also estimated by the volumetric method. The Total Suspended Solids was calculated from the weighted average concentrations of Suspended matters by liquid flow rates [13] the equation.

$$
Q_{s s}=Q_{L} \times C
$$

With,

$Q_{S S}$ representing the suspended solids discharge $\left(\mathrm{kg} \cdot \mathrm{s}^{-1}\right)$;

$Q_{L}$ : the liquid flow $\left(\mathrm{m}^{3} \cdot \mathrm{s}^{-1}\right)$

$C$ : the average concentration of suspended solids $\left(\mathrm{g} \cdot \mathrm{L}^{-1}\right)$.

The annual flux of suspended solids transported by the Abiergue and Mintotomo Rivers was finally obtained by adding the solid contributions of the two stations that feed the lake. BOD was determined by the breathing method using a brand-meter (WTW BOD Model 1020T) using the technique described by Din [14]. COD was determined by oxidation in a potassium medium at a temperature of $148^{\circ} \mathrm{C}$, the oxidizable material under the conditions of the test in the presence of silver sulphate as catalyst and mercury sulfate. For bacteriological analysis, water samples were collected in sterile 0.51 container and the enumeration of bacteria indicative of faecal contamination: total coliforms (TC), faecal coliforms (FC) and faecal streptococci (FS), were performed by filtration through a membrane filter of porosity $0.45 \mu \mathrm{m}$. For much polluted water, a series of dilutions $\left(10^{-4}\right.$ to $\left.10^{-9}\right)$ were conducted. The culture of (TC) was carried out on middle Tergitol 7 agar TTC and incubation at $37^{\circ} \mathrm{C}$ during 24 hours. The culture of (FC) was also performed on middle Tergitol 7 agar VAT, with an incubation at $44^{\circ} \mathrm{C}$ for 24 hours. The enumeration of FS was performed on Slanetz and Bartley after incubation at $37^{\circ} \mathrm{C}$ for 24 hours.

\section{Results and Discussion}

\subsection{Physicochemical Analysis}

\subsubsection{Temperature}

Temperatures $\left(\mathrm{T}^{\circ} \mathrm{C}\right)$ did not vary a lot with the seasons, but was generally higher in the dry season, with values ranging between $23.2^{\circ} \mathrm{C}$ and $23.9^{\circ} \mathrm{C}$ compared to the rainy season $\left(23.1^{\circ} \mathrm{C}-23.3^{\circ} \mathrm{C}\right.$ ) (Figure 2). According to Moumouni Djermakoye [15], high temperatures in water promote the development of microor- 


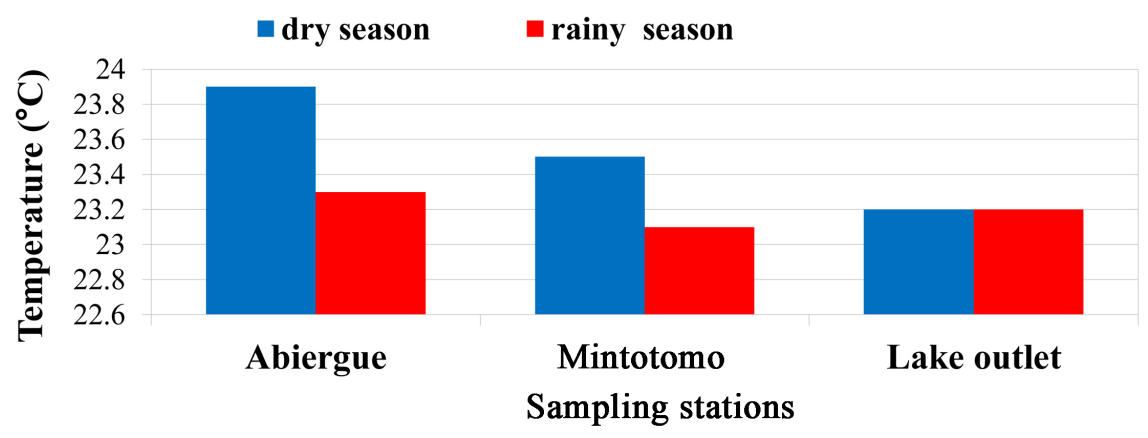

Figure 2. Seasonal variation in temperature.

ganisms, induces unpleasant odour and increases the sedimentation rate of suspended matter. The results of this study are similar to those of Akono Ntonga et al. [6]. Water temperature plays an important role in the solubility of gases, the separation parting of dissolved salts and $\mathrm{pH}$ determination. Water temperature is also important to know the origin of the water and to identify the mixing of different water types is influenced by the source from where they originate [16].

Based on the $\mathrm{pH}$ of the lake water that ranged from 6.90 to 7.20 (Figure 3), the lake is alkaline in nature. The highest $\mathrm{pH}$ values were obtained in the dry season. These results are similar with those obtained in other lakes such as the Yaoundé municipal lake [17], the Ebolowa municipal lake [18] and the Mefou lake [19]. These values could be due to the degradation of organic matter (plants, animals, faeces and domestic waste water).

\subsubsection{Dissolved Oxygen}

Dissolved oxygen (DO) values showed no significant seasonal variation and were generally low $(<6 \mathrm{mg} / \mathrm{l})$. They were higher ( 4 to $5.2 \mathrm{mg} / \mathrm{l}$ ) during the rainy season with the highest value recorded at the lake's outlet while the lowest (3.8 $\mathrm{mg} / \mathrm{l}$ ) was along Abiergue River during the dry season (Figure 4). These results show a strong deficit in DO, with no significant seasonal variation, although we noticed a slight increase at the flood season outfall. Oxygen is known as a good indicator of pollution of waterways and the monitoring of its self-purification. At the studied sites, the DO was low, showing a low photosynthetic activity. This might be due to the extent of pollution of the lake. The average DO value obtained $(<5.2 \mathrm{mg} / \mathrm{l})$ was below the minimum $(>6 \mathrm{mg} / \mathrm{l})$ of DO characteristic of normal biological conditions [20]. These low DO values could be due to the influx of waste water enriched in organic matter and inorganic substances. The values further decreased in the lake due to the degradation of organic matter triggering the multiplication of aerobic microorganisms. If oxygen levels maintain at $3 \mathrm{mg} / \mathrm{l}$, it could lead to the dead of fish [21]. Conversely, opposite results were observed in the Yaoundé municipal lake, (93.3 to $127.6 \mathrm{mg} / \mathrm{l}$ ) [22].

\subsubsection{Electrical Conductivity}

The measure of Electrical conductivity (EC) indicates the degree of water and 


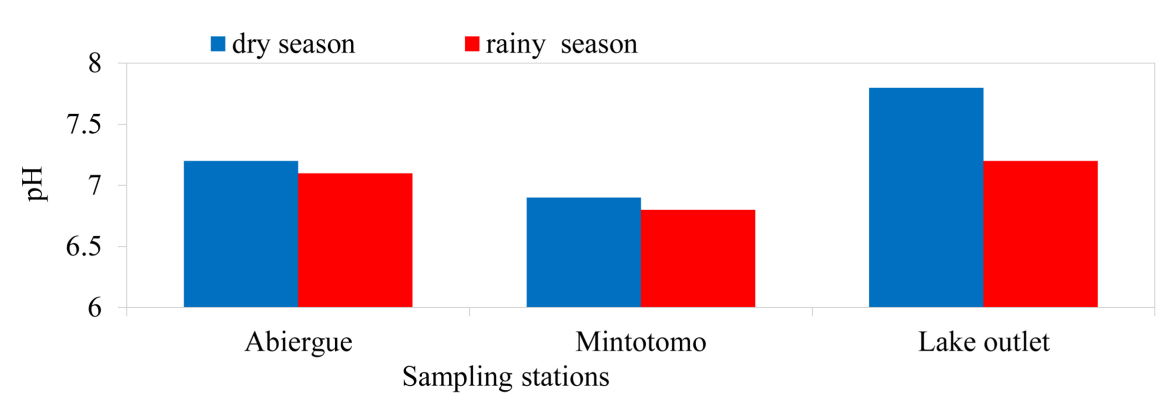

Figure 3. Seasonal variation of $\mathrm{pH}$.

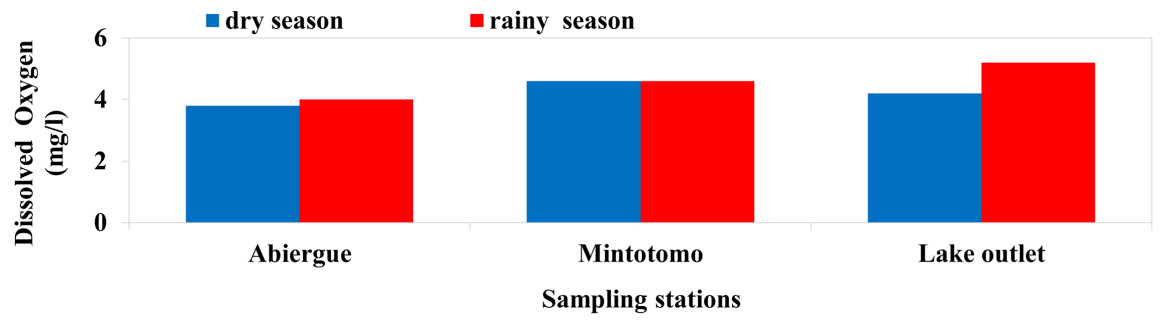

Figure 4. Seasonal variation of dissolved oxygen.

therefore the amount of ionized dissolved substances. Electrical conductivity varied between 90 and $260 \mu \mathrm{S} / \mathrm{cm}$ without a significant seasonal variation. The EC value in the lake was high during the dry season $(279 \mu \mathrm{S} / \mathrm{cm})$, moderate in Abiergue station $(266.1 \mu \mathrm{S} / \mathrm{cm}$ during dry season to $260 \mu \mathrm{S} / \mathrm{cm}$ during rainy season) and low in Mintotomo (92.1 - 87.3 $\mu \mathrm{S} / \mathrm{cm}$ ) (Figure 5). Low concentrations observed at Mintotomo have been described in the Yaoundé [17] and Ebolowa [18] municipal lakes as indicator of an insufficient mineralization [23] and maybe due both to the poor silica-nature of the basement and the load of wastewater in urban areas [24].

\subsubsection{Turbidity}

Turbidity (Turb.) values ranged between 10.2 and 22.4 NTU. The range of values was linked to season. The highest values (10.2 - 22.4 NTU) were observed during the dry season while lowest values (10 - 19 NTU) correspond to rainy season (Figure 6). There was no significant seasonal variation observed at the Mintotomo station. The high turbidity values (22.4 NTU) observed at Lake outlet as described in Taabo Lake in Ivory Coast [25], may be linked both to highly charge water intakes from Abiergue and Mitotomo and also to particles transported during rainfall.

\subsection{Bacteriological Analysis}

\subsubsection{Total Coliform}

The temporal evolution of load in total coliforms (TC) in the three sampling sites showed significant fluctuation between seasons (Figure 7). The time course of faecal coliform concentrations showed that highest values $\left(44 \times 10^{5}-17 \times 10^{5}\right.$ FCU/100 ml) were recorded during floods while during dry season, the levels were relatively low $\left(15 \times 10^{4}-4 \times 10^{5} \mathrm{FCU} / 100 \mathrm{ml}\right)$. The highest concentration 


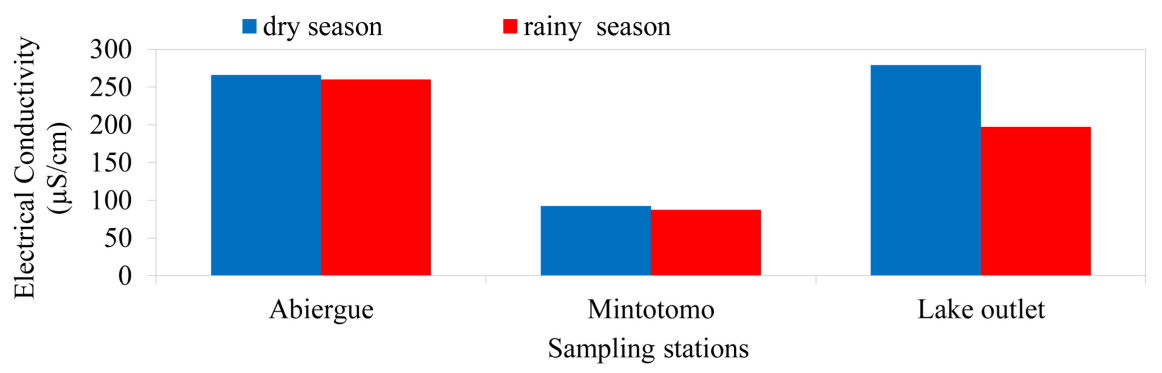

Figure 5. Seasonal variation of electrical conductivity.

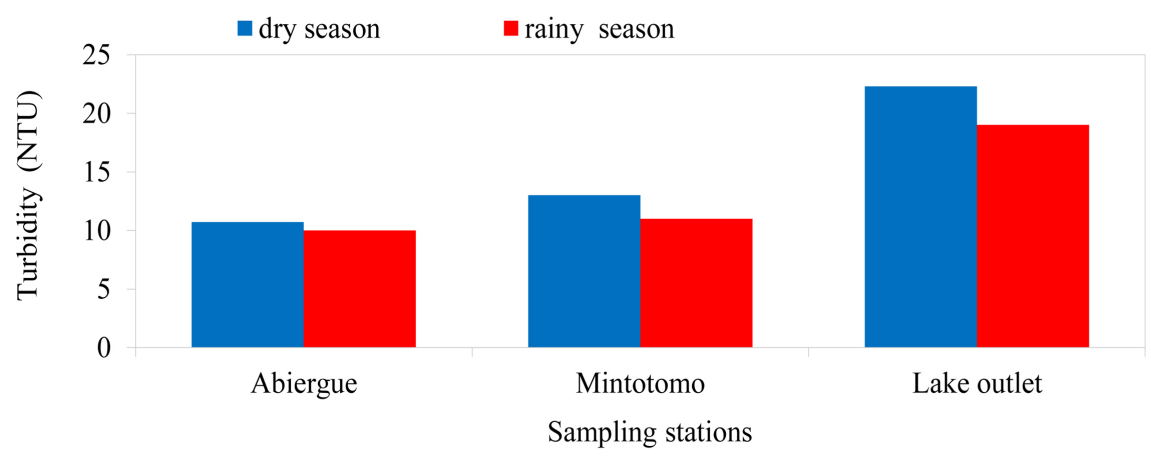

Figure 6. Seasonal variation of turbidity.

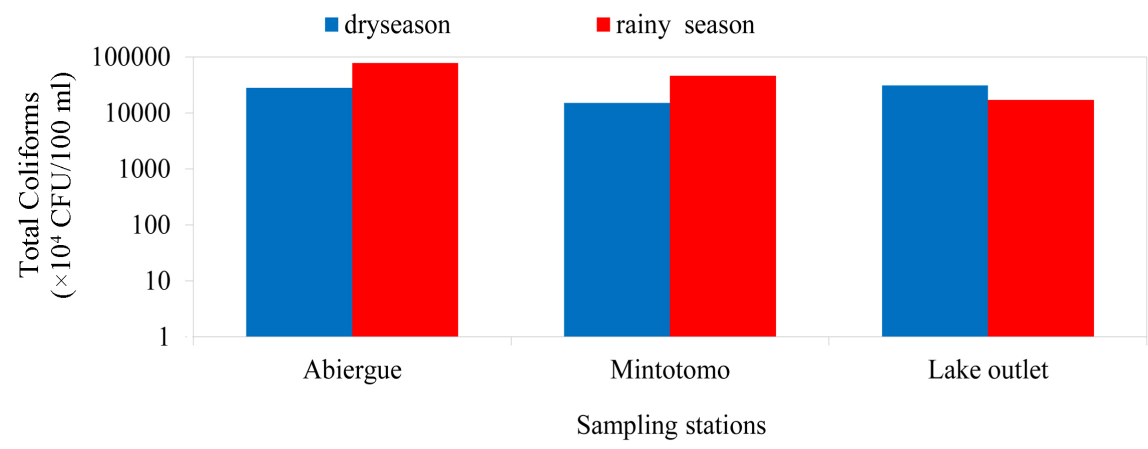

Figure 7. Seasonal variation of total coliforms.

$\left(17 \times 10^{5} \mathrm{FCU} / 100 \mathrm{ml}\right)$ was recorded in the rainy season at the lake outlet while the lowest $\left(15 \times 10^{4} \mathrm{FCU} / 100 \mathrm{ml}\right)$ was recorded at Mintotomo. This massive presence of total coliforms in water is due to the influx of domestic and industrial wastewater into rivers. The TC is known as an indicator of microbial quality of water because it is associated with faecal pollution [26].

\subsubsection{Faecal Coliform (FC)}

Faecal coliform (FC) concentration varied from $10 \times 10^{2}$ to $425 \times 10^{6} \mathrm{FCU} / \mathrm{ml}$. Its spatial variation is closely related to that of total coliform, confirming the water contamination in the studied site by faecal matter. The seasonal variation showed that concentrations varied between $10 \times 10^{2}$ and $425 \times 10^{6} \mathrm{FCU} / 100 \mathrm{ml}$ during the dry season, with the highest and lowest contents respectively recorded at Abiergue and Mintotomo (Figure 8). Whereas during the rainy season, concentrations ranged from 420 to $32 \times 10^{6} \mathrm{FCU} / 100 \mathrm{ml}$, with the highest value 


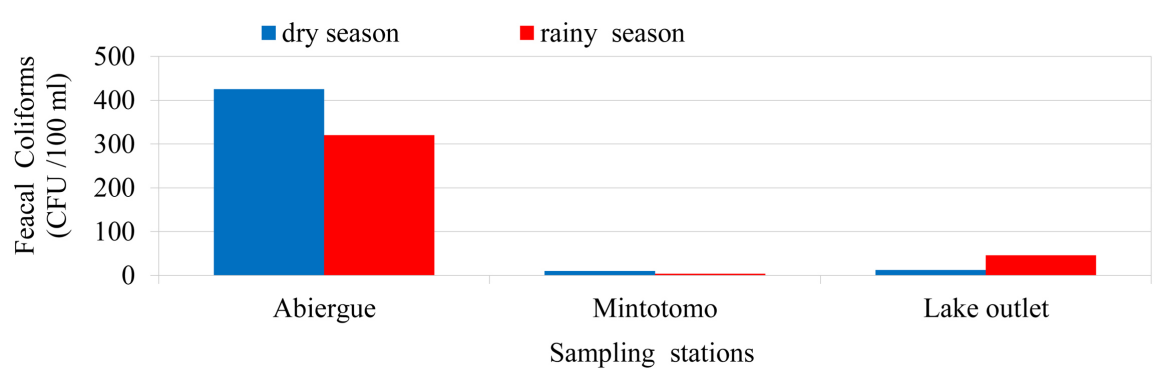

Figure 8. Seasonal variation of faecal coliforms.

found at Abiergue and the lowest is noted at the Mintotomo. These high concentrations might be due to discharges of either urban and domestic wastewater or faecal matter from shallow pit toilets directly into the runway as done by some of the surrounding population [26].

\subsubsection{Faecal Streptococci (FS)}

The FS are associated with faecal coliform, and are considered as good indicators of pollution, and also of treatment because they are significantly more resistant than coliforms and other pathogenic enterobacteria [27]. The amount of FS was generally higher than that of FC in the studied area (Figure 9). At Mintotomo, values of FS were higher during the dry season $\left(158 \times 10^{3} \mathrm{FCU} / 100 \mathrm{ml}\right)$ compared to the rainy season $\left(12 \times 10^{3} \mathrm{FCU} / 100 \mathrm{ml}\right)$. At the Abiergue station, FS varied from $33 \times 10^{3} \mathrm{FCU} / 100 \mathrm{ml}$ during the dry season to $19 \times 10^{3} \mathrm{FCU} / 100 \mathrm{ml}$ during the rainy season. The same trend was observed at the lake with $8 \times 10^{3}$ FCU/100 ml during the dry season and $3 \times 10^{3} \mathrm{FCU} / 100 \mathrm{ml}$ during the rainy season. The highest concentrations were found at the Abiergue and at the lake outlet respectively during the dry and the rainy seasons. This is explained by the accumulation of organic load during the dry season followed by their transport and storage within the lake during the rainy season. During the study period, FC concentration was lower than that of FS and TC compared to faecal coliforms; faecal streptococci are reputed to be resistant to toxic conditions. It has been presented that prolonged exposure to toxic elements and to critical conditions of the medium is more letal for faecal coliforms than faecal streptococci. Ajibade et al. [28] found opposite results in the National Park lake in Nigeria, may be due lack of a constant treatment of the lake water. In general, the results of the bacterial counts indicate a very poor microbiological water quality.

\subsubsection{Determining the Origin of Faecal Contamination ( $\mathrm{R}=\mathrm{FC} / \mathrm{FS}$ )}

The quantification of faecal flora contamination (Table 1) allowed us to follow the evolution of the FC/FS ratio in the three studied sites. In general, this ratio varies from ( 0.23 to 3.97$)$ in the samples assessed. The quantification of the contaminated faecal flora (Table 1) enabled us to follow the evolution of the ratio of faecal coliforms/faecal streptococci at the level of three sites studied. During the two seasons (dry and rainy), the ration CF/SF was between 2.2 and 3.83, and 3.81 and 3.97), respectively at the level of the lake outlet and of Abiergue. The 


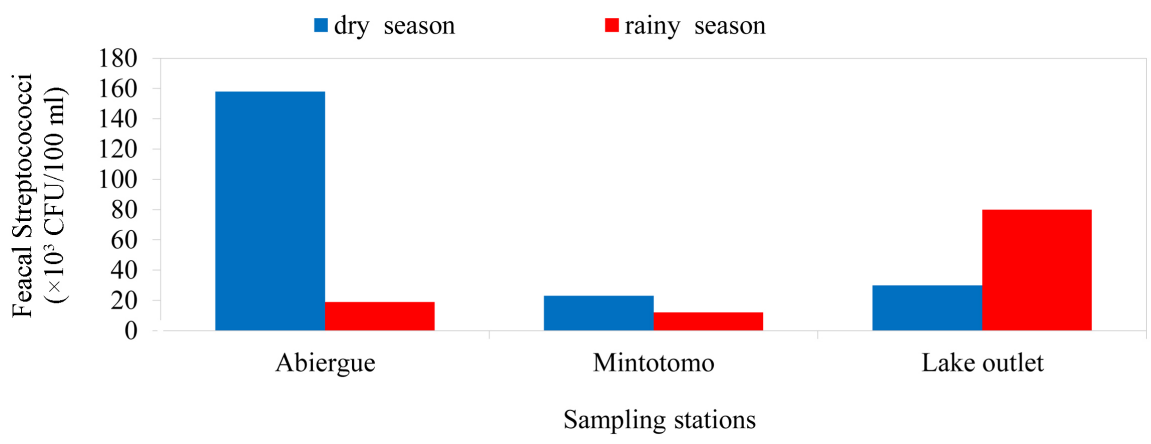

Figure 9. Seasonal variations of faecal streptococci.

Table 1. Origin of pollution according to FC/FS ratio.

\begin{tabular}{cccc}
\hline \multirow{2}{*}{ Sites } & \multicolumn{2}{c}{$\mathrm{X}=\mathrm{FC} / \mathrm{FS}$} & Nature of contamination \\
\cline { 2 - 3 } & dry season & rainy season & \\
\hline Abiergue & 3.97 & 3.81 & $2<\mathrm{X}<4$ (mixed with human dominance) \\
Mintotomo & 0.23 & 0.14 & $\mathrm{X}<0.7$ (strictly animal) \\
Lake outlet & 2.2 & 3.83 & $2<\mathrm{X}<4$ (mixed with human dominance) \\
\hline
\end{tabular}

values of these ratio characterise an origin of mix faecal contamination to human predominance since $\mathrm{R}$ falls between $2<\mathrm{R}<4$. This origin is linked to direct discharge of human excreta into streams by the population living along streams using them as privileged places for defecation [29]. The Mintotomo station either during low water or flood season was marked by contamination of animal origin $(\mathrm{R}<0.7)$ linked to the presence of livestock and leaching of farmlands laden with manure. The discharge of untreated waste water and solid waste into rivers known as a common phenomenon might also be one of the most important sources of microbial pollution in the area. Because of the expansion of cities, hydrosystems currently become the main enabling environment of waterborne diseases [30].

\subsubsection{Biochemical Oxygen Demand (BOD5)}

Biochemical oxygen demand (BOD) is the amount of dissolved oxygen consumed by microorganisms in the dark at $20^{\circ} \mathrm{C}$ for 5 days. It enables the evaluation of biodegradable organic matter present in water; Figure 10 shows an increase of BOD in waters of the study area especially during dry periods. The average values of BOD varied from $8 \mathrm{mg} / \mathrm{l}$ (Mintotomo) and $30 \mathrm{mg} / \mathrm{l}$ (Abiergue) in times of floods and between $9 \mathrm{mg} / \mathrm{l}$ (Mintotomo) and $55 \mathrm{mg} / \mathrm{l}$ (Abiergue) during the dry season. The upstream part of the lake receives raw sewage enriched in organic matter and nutrients from urban centers including Cité verte, Mokolo, Nkomkana and Oyomabang. This causes a significant increase in the organic load of surface waters. The results obtained in this study indicate that the BOD values decrease from Abiergue to Mintotomo. The BOD contents are higher in the dry season compared to the rainy season. This may be due to the fact that during the dry season the flow velocity decreases and waters become warm, 


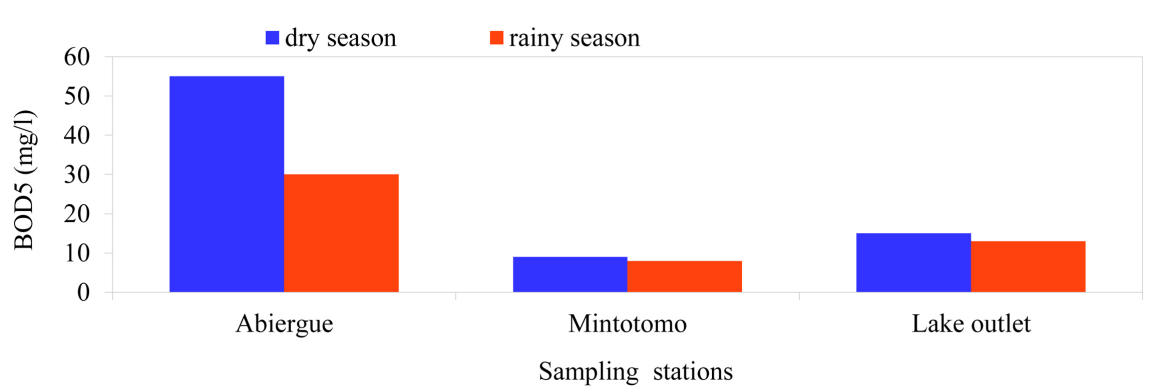

Figure 10. Seasonal variation of biochemical oxygen demand.

providing suitable conditions for the degradation of organic matter by microorganisms. This activity consumes oxygen and results to the self-purification of water [31]. Though, during the rainy season, the rain water significantly contributes to the dilution of organic load from waste water. The Mintotomo station samples are weakly loaded because of its location far from the highly populated neighbourhoods. According to Emere et al. [31], the waters of Abiergue and at the lake outlet are heavily polluted (BOD $>10 \mathrm{mg} / \mathrm{l}$ ) while those of Mintotomo are moderately polluted $(2 \leq \mathrm{DBO} 5 \leq 2.9 \mathrm{mg} / \mathrm{l})$. The same results were found in the water of the Chikila Lake in Indian [32].

\subsubsection{Chemical Oxygen Demand (COD5)}

The measurement of Chemical oxygen demand (COD) is suitable to monitor municipal and industrial wastewater. It is representative both of the bulk organic compounds and of oxidizable mineral salts (sulphides, and chlorides. The COD contents recorded for the studied waters ranged from $16.5 \mathrm{mg} / \mathrm{l}$ (Mintotomo) to $68.8 \mathrm{mg} / \mathrm{l}$ (Abiergue) and between $19.5 \mathrm{mg} / \mathrm{l}$ (Mintotomo) and $76 \mathrm{mg} / \mathrm{l}$ (Abiergue), respectively during rainy and dry seasons. No significant variation between seasons was observed at the lake outlet, (45 - $40 \mathrm{mg} / \mathrm{l}$ ) (Figure 11). High COD values are related to the quality of wastewater and urban domestic water discharged (used as discharge outlet of different waste). The level of COD recorded throughout the study area was generally lower during the rainy season compared to the dry season. Furthermore, during the dry season the contents recorded in all stations are far beyond the WHO and UNICEF standards [33] of $30 \mathrm{mg} / \mathrm{l}$. The increase of COD in the Abiergue station can be explained by the leaching of soils containing inorganic elements. It was noticed that during both the rainy and dry seasons the COD contents of Mintotomo waters remained low. According to Igbinosa and Okoh [34], lower concentrations of COD during the dry season could be attributed to a reduction in organic and inorganic substances in the receiving environment.

\section{Evaluation of Organic pollution}

The ratios of $\mathrm{COD} / \mathrm{BOD}, \mathrm{BOD} / \mathrm{COD}$ (Table 2) provide a very good means to evaluate the level of pollution of waste water and to optimize the physicochemical parameters of waste water which can be useful when proposing suitable treatment methods. 


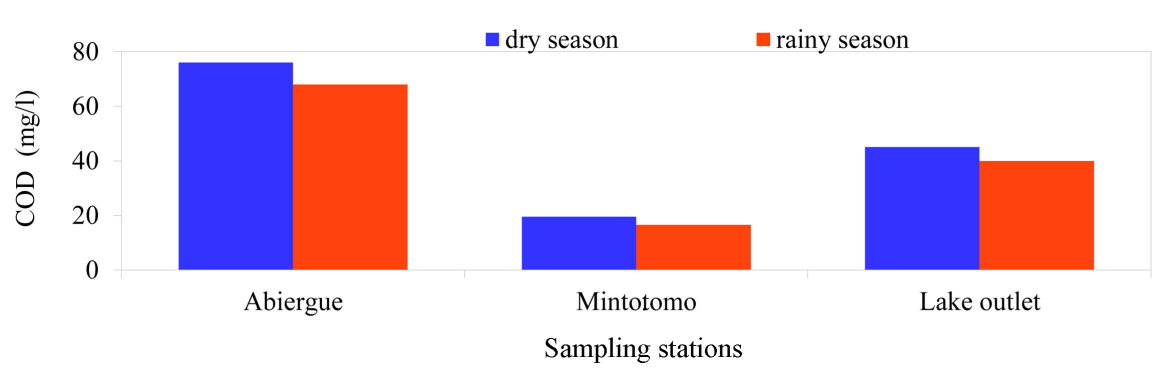

Figure 11. Seasonal variation of the chemical oxygen demand.

Table 2. Expression of the organic load.

\begin{tabular}{ccccccc}
\hline & \multicolumn{2}{c}{ Abiergue } & \multicolumn{2}{c}{ Mintotomo } & \multicolumn{2}{c}{ Lake outlet } \\
\cline { 2 - 7 } Parameters & $\begin{array}{c}\text { Dry } \\
\text { season }\end{array}$ & $\begin{array}{c}\text { Rainy } \\
\text { season }\end{array}$ & $\begin{array}{c}\text { Dry } \\
\text { season }\end{array}$ & $\begin{array}{c}\text { Rainy } \\
\text { season }\end{array}$ & $\begin{array}{c}\text { Dry } \\
\text { season }\end{array}$ & $\begin{array}{c}\text { Rainy } \\
\text { saison }\end{array}$ \\
\hline COD (mg/l) & 76 & 68 & 19.5 & 16.5 & 44 & 40 \\
BOD (mg/l) & 55 & 30 & 9 & 8 & 15 & 14 \\
COD/BOD & 1.38 & 2.27 & 2.17 & 2.06 & 2.93 & 2.85 \\
BOD/COD & 0.72 & 0.44 & 0.46 & 0.48 & 0.34 & 0.35 \\
\hline
\end{tabular}

\subsection{Relationship COD/BOD}

The ratio COD/BOD helps to determine the nature of the pollution of the receiving environment. According to Singh et al. [35] COD/BOD $>2$ means that there is chemical pollution and requires biological treatment. In the present study, the COD/BOD of wastewater of the three studied sites (Abiergue, Mintotomo and Lake Outlet) indicates two categories of outcomes depending on the season. During the dry season, the COD/BOD ratio varied from 1.38 to $3.0 \mathrm{mg} / \mathrm{l}$ and during the rainy season it ranged from 2.06 to $3.08 \mathrm{mg} / \mathrm{l}$ (Table 2). These results characterize a chemical pollution which requires biological treatment. The values obtained $(\leq 3)$ indicate chemical pollution, except Abiergue during the dry season. In fact, low values of the ratio $\mathrm{COD} / \mathrm{BOD}$ involving the presence of a large proportion of biodegradable material and allow considering a biological treatment. Conversely, a large value of this ratio shows that much of the organic material is not biodegradable. Then, in this case, it is preferable to consider a physicochemical treatment. Similar values were observed in wastewater from the city of Oujda in Morocco [36].

\subsection{Relationship BOD/COD}

When characterizing industrial pollution, the ratio $\mathrm{BOD} / \mathrm{COD}$ is often used to provide insights on the origin of sewage pollution and its treatment options. In the present study, the ratio varies from 0.34 to 0.72 during dry season and from 0.35 to 0.48 in rainy season period (Table 2). The values greater than 0.3 during dry season are consistent with those obtained by Nayak et al. [37], and are indicative of a strong inorganic pollution. 


\subsection{Solid Load}

The liquid flow at the entrance of the artificial lake is $560 \mathrm{l} / \mathrm{s}$ ) during the rainy season and $180 \mathrm{l} / \mathrm{s}$ during the dry season. These results are high compared to those observed in most lakes located near large municipalities. The suspended solids (SS) loads carried by the waters of the three sites experience significant seasonal fluctuations (Table 3). The solid load entering the lake varies from $128.4 \mathrm{~g} / \mathrm{l}$ during the rainy season to $13.6 \mathrm{~g} / \mathrm{l}$ during the dry season. While at the lake outlet, the solid load leaving the lake increases to $48 \mathrm{~g} / \mathrm{l}$ during the rainy season and to $2.4 \mathrm{~g} / \mathrm{l}$ during the dry season. The particulate loads are higher during the rainy season when the river flows and suspended matter experience a significant increase. During the course of the hydrological cycle, the particulate matter entering the lake (input) in the rainy season is approximately 4049.22 tons of suspended solids from the Abiergue and Mintotomo against 1513.73 tons of suspended matter at the outlet (output). While during the dry season, the suspended matters drops to 428.89 tons at the entrance of the lake (input) against 75.68 tons at the outlet (output). The increase in suspended solid load during the rainy season could be linked to the contributions from sediments loaded runoff water entering the lake. Bouanani [13] reports that the importance and nature of the suspended solid load are related either to the intensity of erosion by runoff water; thus, the amount of rainfall or to the ability of the flow conveying solids.

The eutrophication of the water body is characterized by the presence of algae and the development of several macrophytes such as Nymphea lotus, Paspalum vaginatum, Ceratophyllum demerson that occur during floods. During low flow periods, these macrophytes disappear under the effect of heat. Indeed, the growth of aquatic plants is causing the formation of a screen to the water surface which prevents the oxygenation in the middle of the lake during flood periods (Figure 12). Furthermore, the decomposition of macrophytes induces an increase in the amount of organic matter in the environment which the degradation therefore favors suffocation of fish species [38]. This may cause an imbalance in the trophic chain (production/consumption) of a body of water and lead to significant ecological consequences [39].

Table 3. Seasonal variations in sediment loads suspended in the Nkolbisson artificial lake.

\begin{tabular}{cccc}
\hline & Rainy Season & Dry Season & Total \\
\hline Liquid inflow (1/s) & 560 & 180 & 740 \\
Suspended matter influx (g/l) & 0.38 & 0.12 & 0.5 \\
Bed load inflow (g/1) & 128.4 & 13.6 & 142 \\
Particulate matter influx (ton/year) & 4049.2 & 428.9 & 4478.1 \\
Liquid outflow (1/s) & 0.3 & 30 & 30.3 \\
Suspended matter outflow (g/l) & 0.16 & 0.08 & 0.2 \\
Bed load outflow (g/1) & 48 & 2.4 & 50.4 \\
Particulate matter outflow (ton/year) & 1513.7 & 75.7 & 1589.4 \\
\hline
\end{tabular}




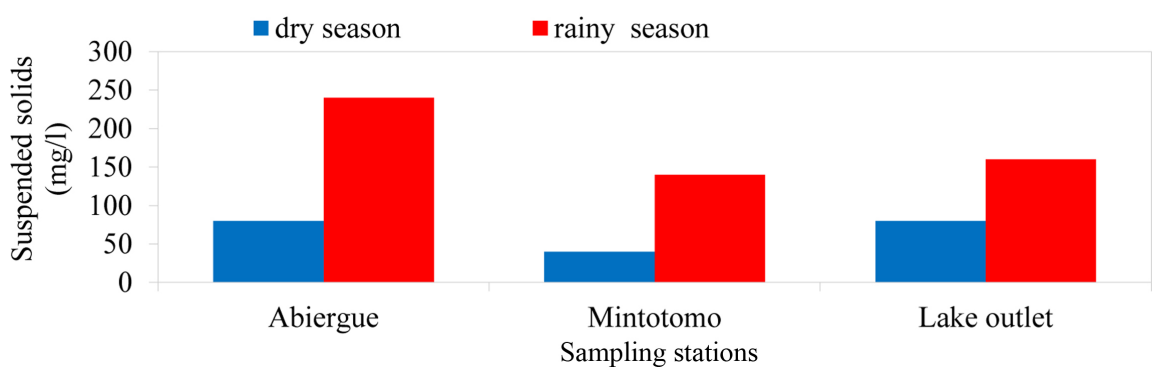

Figure 12. Seasonal variation of the suspended solids.

The discharge of domestic waste contributes strongly to organic enrichment of the Nkolbisson artificial lake because the particulate contributions of output are lower than those of input throughout the study (Table 3).

\subsection{Correlation between Physicochemical Parameters}

The correlation matrix (Table 4) shows that during low flow periods, there is a strong positive correlation both between temperature and fecal coliform $(\mathrm{r}=$ $0.90)$ and between total coliform $(r=0.90)$. These strong correlations are due to the fact that aboriginal bacteria are the dominant components of the total population in the polluted river waters. The electrical conductivity is strongly correlated with $\mathrm{pH}(\mathrm{r}=0.79)$ and suspended matters, due to soil runoff crossed with a strong presence of ions that induce a $\mathrm{pH}$ thus favoring the presence of suspended solids in the water.

There is also a strong correlation between the dissolved oxygen and fecal streptococci $(\mathrm{r}=0.78), \mathrm{pH}$ and turbidity $(\mathrm{r}=0.87)$ and a very strong correlation between faecal coliform and total coliform $(r=0.99)$. Strong negative correlations are observed (between $-0.60 .-0.99)$ between temperature and $\mathrm{pH}(\mathrm{r}=$ $-0.6)$, temperature and turbidity $(\mathrm{r}=-0.91)$; conductivity and DO $(-0.83)$, conductivity and FC (-0.99); $\mathrm{pH}$ and FS $(-0.85)$; Strong negative correlations were also observed between DO and SS $(\mathrm{r}=-0.87)$, FC $(\mathrm{r}=-0.87)$ and FS $(\mathrm{r}=$ $-0.87)$; and between SS and FS (-0.99). Negative correlations are observed between turbidity and FC $(\mathrm{r}=-0.65)$ and $\mathrm{TC}(\mathrm{r}=-0.65)$.

During flood periods, the existing bond between all the variables in pairs and correlation coefficients between these variables were given by the correlation matrix. Table 5 shows that the temperature is strongly $\left(\mathrm{T}^{\circ} \mathrm{C}\right)$ correlated with the following: EC (0.99), $\mathrm{pH}(0.72), \mathrm{SS}(0.94)$ and (TC) (0.95). The conductivity is strongly correlated with $\mathrm{pH}(0.82)$, SS (0.88), TC (0.89). The DO is strongly correlated with turbidity (0.91); TSS highly correlated with TC (0.99) and SF with TC (0.69). The strong significant relationship between temperature and suspended solids is probably related to the fact that the temperature observed during the flood period is favorable to the development of certain bacterial species. Strong negative correlations are also observed between $\mathrm{pH}$ and FC (-0.99), DO and FS (-0.99) and turbidity and FS (-0.94). The correlations between different variables highlight the similarity of the phenomena behind the release of these 
Table 4. Pearson's correlation coefficient between different parameters during the dry season.

\begin{tabular}{|c|c|c|c|c|c|c|c|c|c|}
\hline & $\mathrm{T}^{\circ} \mathrm{C}$ & EC. & $\mathrm{pH}$ & DO & SS & Turb. & FC & FS & TC \\
\hline $\mathrm{T}^{\bullet} \mathrm{C}$ & 1 & 0.02 & -0.6 & -0.57 & 0.08 & -0.91 & 0.90 & 0.07 & 0.90 \\
\hline EC. & & 1 & 0.79 & -0.83 & 0.99 & 0.39 & 0.45 & -0.99 & 0.45 \\
\hline $\mathrm{pH}$ & & & 1 & -0.33 & 0.76 & 0.87 & -0.19 & -0.85 & -0.19 \\
\hline DO & & & & 1 & -0.87 & 0.19 & -0.87 & 0.78 & -0.87 \\
\hline SS & & & & & 1 & 0.33 & 0.50 & -0.99 & 0.50 \\
\hline Turb. & & & & & & 1 & -0.65 & -0.47 & -0.65 \\
\hline FC & & & & & & & 1 & -0.36 & 0.99 \\
\hline FS & & & & & & & & 1 & -0.36 \\
\hline TC & & & & & & & & & 1 \\
\hline
\end{tabular}

Table 5. Pearson's correlation coefficient between the different parameters during the rainy season.

\begin{tabular}{|c|c|c|c|c|c|c|c|c|c|}
\hline & $\mathrm{T}^{\circ} \mathrm{C}$ & EC. & $\mathrm{pH}$ & DO & SS & Turb. & FC & FS & TC \\
\hline $\mathrm{T}^{\circ} \mathrm{C}$ & 1 & 0.99 & 0.72 & -0.50 & 0.94 & -0.10 & -0.62 & 0.44 & 0.95 \\
\hline EC. & & 1 & 0.82 & -0.50 & 0.88 & 0.06 & -0.73 & 0.29 & 0.89 \\
\hline $\mathrm{pH}$ & & & 1 & 0.24 & 0.45 & 0.62 & -0.99 & -0.31 & 0.47 \\
\hline DO & & & & 1 & -0.76 & 0.91 & -0.37 & -0.99 & -0.74 \\
\hline SS & & & & & 1 & -0.42 & -0.33 & 0.71 & 0.99 \\
\hline Turb. & & & & & & 1 & -0.72 & -0.94 & -0.40 \\
\hline FC & & & & & & & 1 & 0.44 & -0.34 \\
\hline FS & & & & & & & & 1 & 0.69 \\
\hline $\mathrm{TC}$ & & & & & & & & & 1 \\
\hline
\end{tabular}

elements in water.

\section{Conclusion}

An investigation into the chemical and biological characteristics of the Nkolbisson artificial lake has been carried out. The study reveals that, the water of the lake is turbid; with conductivity values are higher than $100 \mu \mathrm{S} / \mathrm{cm}$. The results of COD reflect the importance of the content of organic matter at the lake which ranges from $76 \mathrm{mg} / \mathrm{l}$ during the dry season to $68 \mathrm{mg} / \mathrm{l}$ during the rainy season. The low values of BOD indicate the poor content in microorganisms of the waters. The analysis of total coliforms (TC), faecal coliforms (FC), faecal streptococci (FS) indicate pollution from urban districts upstream such as Cité verte Mokolo and Madagascar. The physicochemical and microbiological waters qualities of the study area are far from the WHO guidelines values, and are qualified to be very low. The filling rate of the lake by particulate matter is 2888.7 tons/year representing $64.5 \%$ of the total matter at the inlet. The lake is in an accelerated eutrophication process that led to the current stage of hypereutrophy. 
The imbalance of the ecosystem comes from its continuous supply of organic matters. This study is a scientific showcase and, therefore, a tool to the decision of the authorities of the Yaoundé VII District, from which strong decisions must be made to facilitate the restoration of this urban river system which is rich in aquatic biodiversity.

\section{Acknowledgements}

The present study has been funded by the Research Institute for Development "IRD" and the Norwegian Agency for Development (START/NORAD program). We thank Dr. Joseph Hell (Director of Institute of Geological and Mining Research-Cameroon) and Dr. Jean Claude Ntonga (Cameroon Head of Hydrological Research Centre) for providing logistics.

\section{References}

[1] Barroin (1980) Eutrophisation, pollution nutritionnelle et restauration des lacs. In: Villas, G., Ed., La pollution des eaux continentales. Incidence sur les biocénoses aquatiques, Paris, 75-96.

[2] Gopal, B. and Wetzel, R.G. (1995) Limnology in Developing Countries. International Scientific Publication, New Dehli.

[3] Zebaze Togouet, S.H., Njiné, T., Kemka, N., Nola, M., Foto Menboham, S., Monkiedje, A., Niyitegeka, D., Sime-Ngando, T. and Jugnia, L.B. (2005) Variations spatiales et temporelles de la richesse et de l'abondance des Rotifères (Brachionidae et Trichocercidae) et des cladocères dans un petit lac artificiel eutrophe situé en zone tropicale. Revue des sciences de l'eau, 18, 485-505.

https://doi.org/10.7202/705569ar

[4] Foto Menbohan, S. and Njiné, T. (1998) Distribution et dynamique des populations des ciliés dans deux cours d'eau urbains: l'Abiergue et le Mfoundi à Yaoundé, Annals of the Faculty of Science, University of Yaounde 1, Series, Science, Nature et Vie, 34, 269-279.

[5] N'go, A. (2000) Étude de l'érosion des sols de la région de Buyo : analyse des facteurs et essai d'évaluation des risques par la télédétection et les systèmes d'information géographique. Thèse de $3^{\text {ème }}$ Cycle, Université d'Abobo-Adjamé, Côte d'Ivoire, 155.

[6] Akono Ntonga, P., Bakwo, E.M., Belong, P., Kekeunou, S., Foko, G. and Messi, J. (2010) Abondance et diversité de la faune culicidienne à Yaoundé, Cameroun. Entomologie Faunistique, 62, 115-124.

[7] Bessenassé, M. (2004) Problématique de l'envasement des barrages algériens. Tribune de l'eau n ${ }^{\circ} 631 / 5-632 / 6,39-43$.

[8] Okasha, T., Abdelkader, M. and Med A.T. (2002) Mise en place d'un système d'information géographique pour le suivi et la quantification de l'érosion hydrique: application au bassin versant de l'Isser (Tlemcen). Sécheresse, 13, 175-179.

[9] Christian, F.L., Kenneth, N.B., Daniel, H. and Joseph, A.M. (2010) Spatial and Temporal Variation in Suspended Sediment, Organic Matter, and Turbidity in a Minnesota Prairie River: Implications for TMDLs. Environmental Monitoring and Assessment, 165, 435-447. https://doi.org/10.1007/s10661-009-0957-y

[10] Ryan, A., Harnish, Rishi, S., McMichael, G.A., Langshaw, R.B. and Todd, N.P. (2014) Effect of Hydroelectric Dam Operations on the Freshwater Productivity of a 
Columbia River Fall Chinook Salmon Population. Canadian Journal of Fisheries and Aquatic Sciences, 71, 602-615.

https://doi.org/10.1139/cjfas-2013-0276

[11] Letouzey, R., Gockowski, J., Tonye, J., Baker, D., Legg, C., Weise, S., Tchienkoua, M., Ndoumbe, M., Tiki-Manga, T. and Fouagnégné, P. (2004) Characterization and Diagnosis of Farming Systems in the Forest Margins Benchmark of Southern Cameroon. International Institute of Tropical Agriculture, Social Sciences, 1, 93-102.

[12] Noumon Coffi, J., Mama, D., Dedjiho, C.A., Agbossou, E. and Ibouraima, S. (2015) Évaluation de la qualité physico-chimique et du risque d'eutrophisation de la retenue d'eau de Kogbétohouè (Sud-Bénin). Journal of Applied Biosciences, 85, 7848-7861. https://doi.org/10.4314/jab.v85i1.9

[13] Bouanani, A. (2004) Hydrologie, Transport solide et modélisation: Etude de quelques sous bassins de la Tafna (NW-Algérie). Thèse de doctorat d'Etat, Université de Abou Bekr Belkaid Tlemcen, 249 p.

[14] Din (1982) Study of the Microbiological Pollution of a Malaga Littoral Area II. Relationship between Fecal Coliforms and Fecal Streptococci. VIe Journée étud. Pollutions, Cannes, 561-569.

[15] Moumouni Djermakoye, M.H. (2005) Caractéristiques physico-chimiques, bactériologiques et impacts sur les eaux de surface et les eaux souterraines. Thèse de doctorat, Université de Bamako, 135 p.

[16] Rodier, J., Legube, B. and Merlet, N. (2005) L'analyse de l'eau, eaux naturelles, eaux résiduaires, eau de mer, chimie, physico-chimie, microbiologie, biologie, interprétation des résultats. Ed. Dunod, Paris, $1384 \mathrm{p}$.

[17] Njiné, T., Kemka, N., Zebaze Togouet, S.H., Nola, M., Niyitegeka, D., Ayissi Etoundi, T.P. and Foto Menbohan, S. (2007) Peuplement phytoplanctonique et qualité des eaux en milieu lacustre anthropisé: cas du lac municipal de Yaoundé (Cameroun). African Journal of Science and Technology, 8, 39-51.

[18] Madjiki, G.A., Pial, A.C., Ndam Ngoupayou, J.R. and Amougou, A. (2013) Caractérisation hydrologique, morpho-métrique et physicochimique d'un hydrosystème urbain: Le lac municipal d'Ebolowa (Sud-Cameroun). Afrique Science, 9, 122-134.

[19] Djoko, K.R.P. (2007) Evaluation de la qualité des eaux du barrage de la Mefou à Yaoundé. Physico-chimie et peuplement algal, Mémoire DEA Université de Yaoundé I, $67 \mathrm{p}$.

[20] Kemka, N., Zebaze Togouet, S., Djogo Kenfack, R., Nola, M., Menbohan, S. and Njine, T. (2009) Dynamic of Phytoplankton Size-Class and Photosynthetic Activity in a Tropical Hypereutrophic Lake: The Yaounde Municipal Lake (Cameroon). Hydrobiologia, 625, 91-103. https://doi.org/10.1007/s10750-008-9699-Z

[21] Meinck, F., Stooff, H. and Kohlschütter, H. (1977) Les eaux résiduaires industrielles. 2ème Ed. Masson, Paris, 863 p.

[22] Zebaze Togouet, S., Njine, T., Kemka, N., Nola, M., Menbohan, S., Koste, W., Boutin, C. and Hochberg, R. (2007) Spatio-Temporal Changes in the Abundance of the Populations of the Gatrotrich Community in a Shallow Lake of Tropical Africa. Limnologica, 37, 311-322. https://doi.org/10.1016/j.limno.2007.06.003

[23] Nisbet, M. and Vernaux, J. (1970) Composantes chimiques des eaux courantes, discussions et proportion de classes en tant que bases d'interprétation des analyses chimiques. Annales de Limnologie, 6, 161-190.

https://doi.org/10.1051/limn/1970015

[24] Kouakou, K., Wognin, T., Gnagne, Y.A., N’go, J.R., Courivaud, P., Kassy, M. and 
Deme, K. (2007) Caractérisation des sables et morphologie du fond du lac du barrage hydroélectrique de Taabo (Côte d'Ivoire). Sciences et Nature, 4, 93-103.

[25] Leyral, G., Ronnefoy, C., Guillet, F. and Verne, E. (2002) Bourdais. Microbiologie et qualité des industries agroalimentaire. Paris.

[26] Prescott, L.M., Harley, J.P., Klein, D., Willey, J.M., Sherwood, L.M. and Woolverton, C.J. (2010) Microbiologie. 3ème édition.

[27] Ajibade, W.A., Ayodele, I.A. and Agbede, S.A. (2008) Microbiological Characteristics of Waters in the Major Rivers in Kainji Lake National Park. African Journal of Environmental Science and Technology, 2, 208-216.

[28] Koffi-Nevry, R., Manizan, N.P., Wognin, A.S., Koussemon, M., Koffi, O.S., Kablan, T. and Kakou, C. (2008) Caractérisation de la Répartition Spatio-Temporelle des Bactéries à l'interface Eau-Sédiment D'une Lagune Tropicale: Cas de la Baie du Banco, Abidjan, Côte d'ivoire. European Journal of Scientific Research, 21, 164-174.

[29] Koffi-Nev, R., Assi-Clair, B.J., Koussemon, M., Wognin, A.S. and Coulibaly, N. (2011) Potential Enterobacteria Risk Factors Associated with Contamination of Lettuce (Lactuca sativa) Grown in the Peri Urban Area of Abidjan (Côte d'Ivoire). International Journal of Biological and Chemical Sciences, 5, 279-290.

[30] Bremond, R. and Perrodon, C. (1979) Paramètres de la qualité des eaux. Ministère de l'environnement et cadre de vie. Prevention des pollutions. 2ème éd, $259 \mathrm{p}$.

[31] Emere, M.C. and Nasiru, C.E. (2008) Macroinvertebrates as Indicators of the Water Quality of an Urbanized Stream, Kaduna Nigeria. Nature and Science, 6, 1-7.

[32] Patra, A.P., Patra, N.K., Mahapatra, S. and Swain, G.C. (2010) Seasonal Variation in Physicochemical Parameters of Chilika Lake after Opening of New Mouth near Gabakunda, Orissa, India. World Journal of Fish and Marine Sciences, 2, 109-117.

[33] WHO and UNICEF (2013) Progress on Sanitation and Drinking-Water-2013 Update. Geneva, $40 \mathrm{p}$.

[34] Igbinosa, E.O. and Okoh, A.I. (2009) Impact of Discharge Wastewater Effluents on the Physico-Chemical Qualities of a Receiving Watershed in a Typical Rural Community. International Journal of Environmental Science and Technology, 6, 175-182. https://doi.org/10.1007/BF03327619

[35] Singh, B.K., Srivastava, K.K. and Rivastava, S.K. (2007) Water Quality Assessment Part 1 Urimari Area of South Karanpura Coalfield. Indian Journal of Environmental Protection, 5, 410-419.

[36] Aboueloufa, M., El Halouani, H., Kharboua, M. and Berrichi, A. (2002) Caractérisation physicochimique et bactériologique des eaux usées brutes de la ville d'Oujda: Canal principal et Oued Bounaïm. Actes Inst. Agron. Vet. Maroc, 22, 143-150

[37] Nayak, B.K., Acharya, B.C., Panda, B.B., Nayak and Acharya, S.K. (2004) Variation of Water Quality in Chilika Lake, Orissa, Indian. Journal of Marine Science, 33, 164-169.

[38] Cébron, A. (2004) Nitrification, bactéries nitrifiantes et émissions de N2O. Thèse de Doctorat, Université Paris VI-Pierre et Marie Curie, 289 p.

[39] Dèdjiho, C.A., Mama, D., Tomètin, L., Nougbodé, I., Chouti, W., Sohounhlouè, D.C.K. and Boukari, M. (2013) Évaluation de la qualité physic-chimique de certains tributaires d'eaux uses du lac Ahémé au Bénin. Journal of Applied Biosciences, 70, 5608-5616. https://doi.org/10.4314/jab.v70i1.98763 